\title{
Inter-cultural communications and power relations in international tourism commodity chains
}

The internationalisation of tourism has resulted in the mediation of spatially-stretched commodity chains which often transcend international frontiers and which in businesses from different cultures come into contact with one other. This paper examines the social relations in bilateral business co-operations between Moroccan and German enterprises. As a central concept in the social sciences, there are multiple contested theorizations of power and in this paper we adopt a Lukesian starting point. A more precise naming and locating of power is vital to enhancing our understanding of the way in which the tourism product is commodified.

\section{Power relations and the international- isation of tourism production}

In the past couple of decades there has been a marked increase in the internationalisation of both tourism consumption and production (MOWFORTH/MunT 1998; HOPFINGER/SCHERLE 2003). To satisfy growing demand from tourists for ever more exotic and differentiated experiences, extensive commodity chains have emerged connecting complex arrays of actors and stakeholders (CLANCY 1998; VORLAUFER 1998; Mosedale 2005). These chains are characterised by their extensive reach over space and operation across international frontiers.

From a geographical perspective, the mapping of commodity chains emphasizes not only the dislocation between the points of production and consumption, but also the dependency of producers and intermediaries on tourism generating regions which often differ quite markedly in market conditions. There has been a tendency to attempt to identify the more powerful intermediaries, who act as gatekeepers (IOANNIDES 1997), where power is exercised or measured through the delivery of visitors and/or the extraction of more favorable terms and conditions from suppliers and customers (BASTAKIS et al. 2004). In the following we explore the social relations of commodification in bilateral business relations between Moroccan and German enterprises that form one, admittedly vital, set of links in more complex commodity chains delivering Morocco to German visitors. The aim is to argue that existing pro- nouncements on the nature of the social relations of production in tourism would benefit from a more precise naming and identification of power between actors. As Coles/ Church (2006) argue, there has been a troubling propensity for power and power relations to be invoked as pivotal features in the production of tourism, the negotiation of tourist experiences, and the administration and governance of tourism; however, they are routinely underconceptualised in tourism discourses. Moreover, tourism analysis has become only selectively linked with established and emergent discourses of power, usually those influenced by post-modern and post-structural social theory. Here we contend that further advances in tourism are possible if power discourses are connected with concepts of inter-cultural communication to explore bilateral business relationships (cf. REISINGER/ TURNER 2003; JACK/ PHIPPS 2005). Power is, after all, a culturallyconstructed term, with quite different connotations in different cultures (BOURDIEU 1989; MORRISS 2002). To date, it has been recognised that commodity chains routinely connect enterprises across state borders, but the role of the cultural backgrounds of the interactants and their differing cultures of doing business has for the most part been overlooked.

Foucault's canon of power-knowledge and his wider ruminations on power are currently in vogue in geography (HEROD/WRIGHT 2002; ALLEN 2003) and to a lesser extent in tourism studies (HollinsheAd 1999; CHEONG/MilleR 2000; URry 2002; Hannam 2002). As HaU- 
GAARD (2002) has noted, a number of distinctive bodies of power theory are identifiable with alternative merits. Rather than present a $\mathrm{Fou}$ cauldian reading, we present an analysis based on LUKES $(1974 ; 2005)$ three dimensional views of power, which have had notable resonances in organizational studies (KNIGHTS/ WILLMOTT 1999; BuChanan/BadHAM 1999; Buchanan/ HUCZYNSKI 2004) if not yet in studies of tourism (cf. REeD 1997; DOORNE 1999). We consider actor strategies to power, or, what FEW (2002, after BRown/Rosendo 2000, 212) describes as "the way social groups use their available power resources, or their knowledge and capability to resolve their particular problems." We also consider the specific tactics (measures, devices, technologies), or the micropractices used as part of the actor strategies.

\section{Power and turf games - towards a radical view}

According to CLEGG (1989, xviii), power has for sometime been one of the major concepts in the social sciences: "few terms in the social sciences have engendered as much mystique (fascination, curiosity, fear) as power" (PRUS 1999, 3). For some commentators the power mystique stems from difficulties of conceptualisation and theorisation. LuKES $(2005,61)$ notes the term power is polysemic like the words social and cultural because its precise meaning depends on the context of application. MORRISS (2002) points out there is an extensive Anglo-phone literature on power but many constructs are derived from other languages and hence subject to the particularities of translation (PoGGi 2001; CLEGG 1989; LuKes 2005). Some theorists have viewed power as a capacity, or practically as a quantifiable currency (HINDESS 1996), a valency which may be transferred and traded in zero or positive sum games (PARsons 1963), while Tiger (2000) has argued for conceptualisations of power as a liquid, not a solid. HAUGAARD $(2003,89)$ proposes a seven-fold typology of theorisations on the production of power. It is impossible to discuss the full dimensions and implications of power discourse here (see MANN 1986, 1993; Hindess 1996; HaugaARd 2002; Allen 2003) but there are notable and sometimes extensive differences in substance among the major thinkers. HAUGAARD's (2002) syntheses indicate that all approaches are contested because to one degree or another they are problematic in their ontological, epistemological and/or methodological assumptions or demands. There have been some attempts to bridge the gaps through synthesis (HEISKALA 2001), while several writers have drawn direct comparisons with other prominent thinkers as a means of endorsing their own brand of power theory (cf. LUKES 2005 with Foucault). These differences are far from trivial because, as LUKES (2005, 12) observes: "... how much power you see in the social world and where you locate it depends on how you conceive of it, and these disagreements are in part moral and political, and inescapably so." Clearly then, it is important to use precision in the naming and locating of power. ALLEN (2003) argues that there are several modalities of power -including domination, authority, coercion, manipulation and seduction - that are understood ontologically and revealed empirically in different ways. Divergence also implies that ontological and epistemological decisions that involve the selection of a single (i.e. dominant) body of power discourse are almost inevitably and inherently subjective rather than objective (cf. AlLEN 2003). Thus, while Foucauldian approaches may have enjoyed recent popularity, this is not necessarily because they are unproblematic nor the most appropriate to research topics, but sometimes because of intellectual fashion and how we discipline ourselves as academics (TRIBE 2003).

More inclusive, plural treatments of power are, for instance, evident in studies of business organizations (MCKINLAY/STARKEY 1988; ClEGG 1989; KNIGHTS/WILLMOTT 1999; BuCHANAN/ HUCZYNSKI 2004). Lukes' ideas, like those of Foucault and others (MCKINLAY/STARKEY 1998; KNIGHTS/Willmott 1999; KNIGHTS/MCCABE 2002), offer a framework through which to explore the motives and behaviours of individuals and collectives, as well as the operation of particular modes of power. LUKES' (1974) so-called Radical View was based on his dissatisfaction with, and extension of, work undertaken by elitism and pluralism in American political science in the $1950 \mathrm{~s}$ and $1960 \mathrm{~s}$ (Thomas/Thomas 2005; COLEs/Church 2006). LUKES' (1974) major conceptual achievement was the identification of three dimensions to power (summarised briefly in Tab. 1). In this behaviouralist perspective, his three dimensional views of power are revealed through the unfolding outcomes of social relations and processes. Decision and non-decision 
making, observable and latent conflict, ideology and the control of the agenda have immediate resonances with processes, settings and structurings in commercial behaviour over bids, tenders, contracts, delivery, evaluation and the like. The identification of power in this manner has though been questioned. LUKES (2005) notes that he is guilty of the exercise fallacy, or the reduction of the identification and assessment of power to the observation of its exercise, which impedes the observation or measurement of power as disposition (MORRISS 2002, 15). LUKES $(2005$, 64) concedes that there are difficulties with how to deal with multiple power relations among stakeholders and where unitary interests are lacking. Several commentators have pointed to difficulties in how to know or identify the third dimensional view of power (BENTON 1981). KNIGHTS/ WiLlmotT $(1999,97)$ contend that Lukes' framework requires a priori knowledge of real interests and that interests are a product of the exercise of power, and not, as Lukes postulates, pre-existing, pre-ordained features that dictate the course and nature of power relations. Indeed, the notion of real interest is questioned. Whereas Lukes considers real interests to be manipulated by the exercise of the "Third dimension of power" (LUKES 1974), KNIGHTS/ WiLlmotт $(1999,98)$ point to the difficulties in (legitimately) justifying such attributions.

Lukes' ideas offer two interpretative sets of potentials here: they help to explain how power strategies emerge, while simultaneously they offer a broad conceptual platform from which

Tab. 1: The three dimensional views of power

\begin{tabular}{|c|c|c|c|}
\hline View of Power & Nature of view & Focus on & In a nutshell \\
\hline One-dimensional & $\begin{array}{l}\text { Behaviouralist, } \\
\text { pluralist }\end{array}$ & $\begin{array}{l}\text { - Behaviour } \\
\text { - Decision-making } \\
\text { - (Key) Issues } \\
\text { - Observable (i.e. over) } \\
\text { conflict } \\
\text { - (Subjective) Interests, seen } \\
\text { as policy preferences } \\
\text { revealed by political } \\
\text { participation }\end{array}$ & $\begin{array}{l}\text { Power that is exercised } \\
\text { to secure a decision in } \\
\text { situations where there is } \\
\text { some observable conflict } \\
\text { or disagreement. }\end{array}$ \\
\hline
\end{tabular}

Two-dimensional (Qualified) Critique - Decision-making and nonof behavioural focus decision-making

- Issues and potential issues

- Observable (overt or covert) conflict

- (Subjective) Interests, seen as policy preferences or grievances
Power that is exercised to keep issues on or off the decision-making agenda, so that potential conflicts or disagreements are precluded and therefore unobservable.
Three-dimensional Critique of behavioural focus
- Decision-making and control over the political agenda (not necessarily through decisions)

- Issues and potential issues

- Observable (overt or covert) conflict and latent conflict

- Subjective and real interests
Institutionalized power that is exercised to define social reality. To the extent that norms and meanings are internalized, people accept and thereby reproduce the power-invented definition of reality, even when this is against their 'real' interests. 
to explore further the micro-practices of power in organizations. BUCHANAN/ BADHAM (1999) note plurality and synthesis as a means of overcoming shortcomings in individual fiats of power theory, and they identify power as an individual property, a relational property, and as an embedded property. In the latter, power is understood to be a function of regulations, structures, systems and the like in which the organization or the individual within an organization function, and here they point to the contribution of Lukes in setting the rules of engagement for decision- and non decisionmaking. Power as an individual property is effectively an alternative discussion of power as a capacity, a disposition, with the identification of a series of what they term structural and individual sources of power from which basic valorisations of power to (potentially) achieve particular outcomes are possible. Power as a relational property merely rehearses arguments on power as a relational construct (LATOUR 1986).

BUCHANAN/ BADHAM (1999) draw on perspectives from social psychology to explore how power is perceived by actors relative to one another. All too often, as BRUINS $(1999,7)$ points out, there has been a tendency in power discourse to theorise and explain at the intergroup (societal) level rather than the inter-personal level. Based originally on the work of FRENCH/ RAVEN (1959) respectively RAVEN $(1965,1974,1992)$ six bases of power are identified: reward, coercive, referent, legitimate, expert (RAVEN 1959) and informational power each form a basis for the unfolding of power in social relations (RAVEN 1965) (Tab. 2). BACHRACH/ LAWLER $(1980,34)$ refined
French's and Raven's work to differentiate between bases of power - "what parties control that enables them to manipulate the behaviour of others" - and sources of power, or "how parties come to control the bases of power". They identified four bases and four sources of power (Tab. 3), while BENFARI et al. (1986) identified eight bases towards the effective use of power - reward, coercion, authority, referent, expert, information, affiliation, group - and that bases may have a positive or negative function (RAVEN 1992). Subsequent studies have suggested that from the bases and sources of power a series of discrete influence tactics exist that are intended to help secure their practitioners' desired outcomes (Tab. 4, KIPNIS et al. 1980, 1984; YUKL/FABLE 1990; RAVEN 1992) as well as diagnostics that reflect an individual's power relative to other actors' (HUCZYNSKI 1996; BADHAM/BUCHANAN 1996).

BUCHANAN/ BADHAM's (1999) application of these concepts is important because they demonstrate that the social world is messy. There are differences between the way power is theorised in artifically santised ways by scholars and how it is often imperfectly understood and untidily applied in everyday lives and operations. Methods and conceptual frameworks are necessary that will allow the full complexity of the social relations to be revealed (LAW 2004). A more tactical approach allows power to be named, located, valorised, and exercised in various individuals' strategies to guide themselves through rudimentary or complicated, subtle or even plainly coarse turf games inside and between organizations. Power may be exercised in a quite sophisticated

Tab. 2: FRENCH/ Raven's (1959) bases of power

Base of power $\quad$ Basis of power is...

Reward power $\quad \mathrm{P}$ 's perception that $\mathrm{O}$ has the ability to mediate rewards for $\mathrm{P}$

Coercive power $\quad \mathrm{P}$ 's perception that $\mathrm{O}$ has the ability to mediate punishments for $\mathrm{P}$

Legitimate power Perception by $\mathrm{P}$ that $\mathrm{O}$ has a legitimate right (authority) to prescribe behaviour for $\mathrm{P}$

Referent power P's identification with $\mathrm{O}$ or the feeling of 'oneness' of $\mathrm{P}$ with $\mathrm{O}$, or a desire for such an identity. $\mathrm{O}$ has attributes and abilities that are seen as charismatic by $\mathrm{P}$.

Expert power $\quad \mathrm{O}$ has some special knowledge or expertise that makes $\mathrm{P}$ in some way perceive $\mathrm{O}$ as superior.

Informational power $\mathrm{O}$ has information that $\mathrm{P}$ perceives as important. 
manner by certain individuals and their organisations; however, it may feature in straightforward, even imperfect ways through simple calculations of bases and sources of power (RAVEN 1992). Decisions stem from what BACHRACH/ LAWLER $(1980,7)$ term a series of "competitive tactical encounters" in which influence, authority, bargaining and compromise contribute to the best resolution at any given time (BADHAM/Buchanan 1999, 41). Moreover, such a perspective highlights that it is not only the apparently most powerful that participate in power struggles because "even being down-trodden, voiceless and marginalized is to possess a power source which can be exploited, if and when circumstances allow" (BUCHANAN/ BADHAM 1999, 49). As Bugental/ Lewis (1999) have noted, the seemingly powerless adopt control-oriented strategies when their authority is challenged: to be powerless does not necessarily imply that an individual is bereft of deliberate strategies or tactics towards power.

Studies of inter- and intra-organizational power relations reveal the importance of organizational settings in framing and shaping behaviours. These studies have, though, considered organizations from the same or similar cultural backgrounds. Not only is power culturallyconstructed (see MoRRISS 2002), but so are business practices and so-called power differences, the perception of which are vital to com- mercial transactions between businesses from different cultures.

\section{Tourism and intercultural communication}

As JACK/ PHIPPS $(2005,6)$ argue, tourism is an "inter-cultural activity, constructed within and through language, has been largely ignored in tourism research until very recently."; simply put, what limited attention there has been has focused primarily on host-guest encounters (HUNTER 2001; REISINGER/TURNER 2003) rather than business-to-business relations (cf. SCHERLE 2004, 2006). Inter-cultural communication has become a major focus for management studies. Mainly driven by HoFSTEDE's work (1982, 1999), such studies have courted controversy (MOOSMÜLLER 1997; BRANNEN 2003; THOMAS 2003). One of the more important reasons for this is that there is a propensity to reduce culture to a mere factor, practically an ingredient that has to be present in successful international business (JOHNSON/ TURNER 2003; Rugman/HodgetTS 2003).

Inter-cultural communication depends heavily on the notion of inter-cultural competence. Intercultural competence is the mutual avowal of the interactants' cultural identities where both interactants engage in behaviour perceived to

Tab. 3: BACHRACH/ LAWLER's (1980) bases and sources of power

Bases of power

Coercive power

- Ability to apply the threat of sanctions

Remunerative power

- Control of material resources and rewards

Normative power

- Control of symbolic rewards

Knowledge

- Control of unique information that is required to make a decision.
Sources of power

Office or structural position

- The position or structural location might provide a party access to various bases of power.

Personal characteristics

- Charisma and leadership as manifestations of personal abilities and characteristics that key individuals have apart from other sources of power.

Expertise

- Specialized information that actors have come to control and apply to particular issue.

Opportunity

- Located in informal settings, come to control information that is of importance to others. 
be appropriate and effective in advancing both cultural identities (COLLIER 1989). KÜHLMANN/ STAHL (1998) identify seven characteristics to facilitate intercultural competence: tolerance of ambiguity, behavioural flexibility, target orientation, sociability, empathy, polycentrism, and meta-communicative competence. While each of these facets operates differentially, all should be present in competent and effective intercultural engagements, and abstract tolerance alone is rarely effective (MoOsMÜLLER 1997; SCHERLE 2004).

Two schools of thought have emerged concerning the relevance of culture in international business. Culturalists advocate that management techniques are intricately and mutually implicated with culture, or international business is culture-bound. Businesses have to be more culturally competent, sensitive to the needs and operations of their partners in other cultural settings, thereby adjusting and gearing their own operations accordingly. The culturalist position is challenged by the universalists. For them, management techniques are universal and therefore independent of culture-specific influences; business is culture free, low levels of intercultural competence are required, and operations need minimal, if any adjustment to cater for bilateral business co-operations. The culture-free and culture-bound positions have been contested (see OSTERLOH 1994; HOFSTEDE 1999). While it may be tempting to use broad cultural designations, cultures are constantlyevolving and highly differentiated into microcultural sub-systems. Such fissures and cleavages hint at how tensions form; they help to explain divergence and exceptional behaviours in bilateral co-operations (MOOSMÜLLER 1997); and significantly they expose the use of stereotypes in intercultural management.

Thus, there is a paradox in that power is central to the mediation of these inter-cultural business relations, but power discourse has not been wired into studies of inter-cultural business communications. This is a notable omission because, even where inter-cultural competence is high, conflicts cannot be eliminated altogether (GILBERT 1998). In fact, conflicts are relatively common occurrences and competitive tactical encounters involving power are routine in cross-cultural business relations. Questions arise therefore of how the individual protagonists perceive their positions over power, the power strategies and tactics they are prepared to use in conflict situations, and how their approaches to power map against their other organizational characteristics. Furthermore, conflicts frequently have a cultural background and they occur with the interaction of interdependent people who perceive incompatible

Tab. 4: Power influence tactics in organizations

Scale of influence tactics

Definition

Pressure tactics Use of demands, threats or intimidation to secure compliance.

Upward appeals Use of persuasion to persuade another that the request for compliance is approved by higher management.

Exchange tactics Use of explicit or implicit promises that rewards or tangible benefits will result from compliance with request.

Coalition tactics Aid of others is used to persuade an individual to do comply with a request.

Ingratiating tactics By means of getting an individual in a good mood, requests for compliance will be met more positively.

Rational persuasion Use of logical arguments and factual evidence to persuade an individual to comply with a request.

Inspirational appeals Emotional request of an individual to secure compliance by appealing to the values and ideals of an individual.

Consultation tactics Use of consultation or the opportunity to input to decision-making or planning in order to secure compliance to a request. 
goals and interference from each other in achieving those goals (MORAN et al. 1993; HOCKER/WILMOT 1985). KOPPER (1992) identifies two principal, idealised approaches to conflict management. Individualistic cultures deal with conflicts in a more dispassionate, matterof-fact way. They are designed to get beyond the implications for particular individuals and instead work towards the future of the organization. They are based - in theory at least - on a rational and objective assessment of the circumstances. When mapped against intercultural management approaches, there are obvious overlaps with the culture-free approach. In collectivist cultures, conflict management is more culturally-bound. Conflicts are viewed negatively, as more destructive forces; they are constructed and resolved in more emotive, subjective and ambiguous ways; and they are associated with individuals and groups whose status is questioned during the conflict.

Of course, individual and collectivist organisations may use any or all of the tactics outlined in Tab. 4 depending on the precise circumstances of a conflict. However, there is a suggestion that individualist, culture-free organisations may be more predisposed towards rational persuasion, exchange tactics and reward tactics given their devotion to the one best way. In contrast, collectivist organisations where culture and business are intricately and messily bound, inspirational appeals, coalition tactics and consultation tactics may be more prevalent. This concern for tactics should not mask the importance of conflict management as a source of power. For conflicts to be resolved, especially where the protagonists originate from individualistic and collectivist cultures, there has to be a mutual recognition of each other's approach. Joint dialogue may advance creative solutions to improve future cooperations and it improves the actors' insights into, and understandings of their counterparts behavioural patterns (DE DREU 1997; SCHNEIDER/BARSOUX 1997).

\section{Conflicts between German and Moroccan businesses}

In order to explore the relationships between Moroccan and German businesses, a series of qualitative interviews was conducted between July 2000 and January 2002 (see SCHERLE 2004, 2006). In total over 60 interviews were completed and during these interviews business attribute data was collected alongside information on their bi-partite business relations with partners in Germany and Morocco. In both samples, over $50 \%$ were established businesses that had been operating for over ten years, over $60 \%$ had fewer than 50 employees, and there were similarities in the levels of professional training. Few had direct training in intercultural business management. Nevertheless, all but one German business had been cooperating for over a year, there was a relatively even spread of the durations of intercultural co-operations among firms in the two samples, and approximately $60 \%$ of the individual German and Moroccan respondents had experience of intercultural business relations.

Sources of conflict for German businesses German business persons perceived conflicts in how their Moroccan partners connected their organizational behaviours to their religious and cultural practices. Ramadan, the month of fasting, and its implications for co-operation, was a particular and frequent source of contention. As the manageress of a small incentive operator observed, Ramadan impacts not only on the potential to conduct everyday business, it is perceived to have a direct impact on person-toperson interactions: "I have experienced little willingness to compromise, to adapt to Western culture; Ramadan being of course a good example... This fasting has a tremendous impact. You notice an irritability, and the whole tempo is of course slowed down. (...) It affects our direct partners, who I'm talking about, who on their part are also dependent on their partners, i.e. the hoteliers, the people who rent out fourwheel-drive vehicles, the restaurants and so on, so that this slowing down practically multiplies. (...) And it is a really big problem that the German tour operators who should know about it also don't understand. They just come and say 'We need an answer tomorrow!', and when they [the Moroccans] say, that is not possible, you know that', then they [the German tour operators] say 'that's your problem!'”

Three features are revealed by this response: first, how easily and explicitly German interviewees' intercultural ignorance was exposed; second, the degree to which they were intolerant of differences, although many had intercultural experiences; and third, the magnitude of their concerns over the commercial difficulties presented to their businesses. Many other inter- 
viewees articulated the consequences of $\mathrm{Ra}$ madan for incoming tourists, such as restrictions in service which, in turn, lead to customer complaints and strained co-operations. Perhaps more concerning is that German business persons wanted a liberalisation of trade from the perceived constraints exerted by religious doctrine (NIENHAUs 1996).

Personal relations played a central role in Morocco to a level that frequently troubled the German respondents. Friends and relatives were frequently employed in the Moroccan businesses. Such interpersonal contacts are established and cultivated in Arab countries not only at business meetings but also in private settings. The intention is to create a network of trust which fulfils a crucial function giving security in countries that are traditionally associated with corruption (KURAN 2004). Despite a basic awareness of these linkages, German respondents underestimated the role and outcomes of employing relatives. Within the (larger) German tour operators with pronounced horizontal and vertical business structures, such personalised business structures were judged as disconcerting. They had a propensity to induce acute conflicts in the day-to-day negotiation of business. A product manager of a leading German company summed up the frustrations of many German interviewees: "One Moroccan firm we work with is closely linked to family. You'll hardly find a firm where people not belonging to the family occupy key positions. Qualifications aren't important at all! That means, from the very beginning you have to expect great weaknesses in personnel because there are always positions, important positions, which are occupied in this firm by people who don't have the capacity, the knowhow." The product manager added that he could understand practically no personnel decision made on the Moroccan side in the last few years. While this may have been melodramatic, the consequences of familial business structures for practical co-operation remained tangible such that German partners assumed the lead in their dealings with Moroccan partners: "Over the years we have learned to take on more and more responsibility. That is, when they weren't pure agency tasks such as bus planning or day trip planning, tour leaders, local guides, then we took everything over. (...) So that we relied less and less on the partner's agreement, especially in fundamental decisions, such as personnel decisions."
The gendered social relations of tourism production were identified by several interviewees as sources of irritation. Despite all attempts at modernisation in recent years, North African women still have a largely traditional image, bound to a religious and patriarchal value system oriented around the Koran. In a male-orientated tourism industry such as the Moroccan, the presence of a high proportion of women in senior positions among their German counterparts created friction. Overall, this issue was not as problematic as either working practices or familial structure but it resulted in several poignant, troubling experiences for the female interviewees concerned. One product manager of a medium-sized German tour operator observed that in her experience, "Not every Muslim, Arab or Moroccan is open-minded enough to let a woman give him orders. I noticed that when I started to work in Morocco. The first three months were very hard, because they just tried to say: 'you woman, you European, you can't tell us anything.' Until one day the penny dropped, the tune changed, and after about three months I noticed, ah, they're accepting me as a woman, they're accepting what I say and they see that the work I do is good and gets results."

Sources of conflict for Moroccan businesses In their collaborations with their German partners, Moroccan interviewees identified economic sources of conflict. The apparent profitability of German businesses, asymmetrical flows of information and capital, and the perception that the viability of Moroccan companies was irrelevant to their German partners were frequent, strongly-articulated complaints. One product manager of a medium-sized incoming-agency from Casablanca epitomised this view: "The negative aspects in co-operation are reflected most especially in the fact that continually less is paid and more quality is expected. Our outgoings are too high in relation to the price paid."

Relatively frequently Moroccan interviewees bemoaned financial arrangements in bilateral co-operation. For example, the manager of a small agency from Tangiers articulated the view that German mismanagement induces problems for the (seemingly) powerless Moroccans: "In Germany there are at the moment many firms which go bankrupt. Many of these agencies have no finances! That is a risk and we have been affected twice: once by an Aus- 
trian agency with 120000 Schillings [outstanding debt] and a second time with a German agency with 16000 Marks. You know that that is a lot of money for us. When we lose 16000 Marks that corresponds to the profit from 15 groups [of visitors] (...) We cannot cope with such a loss...".

Clearly, Moroccan interviewees were aggrieved at being expected to trust the good name of the German partners without the same status being afforded them in return. In fact, because of disadvantageous experiences with their German partners over finance, trust had been divorced from its purely moral meaning. Instead, as the ironic comments below make clear, trust had assumed a more calculative meaning as an outcome, not the foundation of a transaction: "There is one important thing: for us, trust is synonymous with money. Personally, if I don't know you - even if I find you congenial - you would not be allowed to send me your group before we have checked the billing. That's trust! (...) That's the reason why trust is synonymous for us with money. Pay me in time, I trust you. We could allow some days of delay, but it should not last too long."

Some Moroccan tour operators repeatedly referred to financial problems which stemmed from rationalisation in the German tourism sector through takeovers and insolvencies (VORLAUFER 1998; BASTAKIS et al. 2004). This led to increased competition, especially among small Moroccan agencies, for collaborations with the diminishing number of German players in the market. The trans-national activities of the larger overseas operators were viewed as threatening smaller-scale indigenous enterprises in Morocco. Whether rational or not, fear of globalization was followed by the view that the takeover of local businesses would put further pressure on other types of businesses elsewhere in the tourism value chains in a destination: "Globalization is a problem for many incoming agencies. In three or four years the huge touroperators will take over all the small agencies. That's not good at all for small destinations like Agadir." Many small operators had to forge alliances with one or more of the best-known (larger) German tour operators. While this broadened their product range, they had hoped to obtain further insurance against market conditions and fluctuating demand. This had served to empower the German partners because there were fewer of them, they were being chased by broadly the same number of potential Moroccan partners, and they felt they could establish better terms from their potential partners. The situation conspired to make the smaller Moroccan businesses feel more vulnerable still: many forms of co-operation were not based on contractual agreements, with the result that German tour operators could switch partners and operating conditions relatively easily.

\section{Conflict Resolution: Intercultural Perspectives} Three principal approaches were identified as overwhelmingly popular and highly successful for both German and Moroccan interviewees: "open discussions when needed" ( $>90 \%$ of respondents); "employee discussions" (>50\%); and "regular team meetings" (>32\%). In each case less than $7 \%$ of the businesses that employed these tactics reported poor success. "Legal resolution" and "management consultants" were used as conflict resolution by less than $5 \%$ and $2 \%$ of businesses respectively and each had poor success. Fewer than $17 \%$ of businesses attempted to solve conflicts by "pressure and compulsion", "arbitration", "intercultural training", and "reputation" alone, and these were viewed by less than $7 \%$ as successful (see SCHERLE 2006 for a fuller discussion). Thus, the most frequently applied and successful methods were those that had a clearly personalised and discursive nature. The small- and medium-sized nature of the businesses interviewed, combined with the often long-term nature of their bilateral relationships, meant that many had great volumes of social capital invested with their partners. Rather than recourse to the law or investment in more expensive solutions such as management consultants or intercultural training programmes, the businesses could fall back on their close personal contacts in order to fashion a solution through dialogue. Moreover, such solutions were often characterised by remarkable pragmatism on both sides. As one manager of a German tour operator wryly observed: "I always say that there is a legal and a business solution ... and we are always for the business solution, although I am a lawyer. This sector is much too small for legal solutions. In the 30 or 20 years I have been working, I have only twice gone for the legal solution and every other time the business solution. You keep running into people!"

A senior employee of a Moroccan incoming agency in Agadir noted in a similarly realistic 
manner that "we compromise so as not to lose our partner and to have work all year round." This sentiment was repeated frequently, and it encapsulated a common anxiety among Moroccan partners: not only could they be the victims of commercial exploitation by their overseas partner, but also that they were too vulnerable to failure as a result of the increasing globalisation of tourism production and consumption. Increased concentration among German tour operators and the disappearance of previous partners provoked many small- and medium-sized Moroccan operators to sense themselves as more open to exploitation because of the greater difficulties in establishing beneficial collaborations. As the managing director of an incoming agency in Agadir opined: "It is becoming more and more difficult to find business partners, as globalisation is made for those who are already strong and who become even stronger with globalisation. When you talk about globalisation you have to automatically think of the three large groups in the Moroccan market: TUI, Neckermann [now Thomas Cook] and LTU. These are the biggest, who will benefit, and for us everything will get harder."

There were also complaints that the purchasing power of the large groups is growing, and that local tourism businesses may be further marginalized, especially in the centres of mass tourism (primarily Agadir), where the global players are established and dominant in all types of tourism. Interviewees noted variations in outlook for co-operations in different markets. Moroccan agencies specialising in narrow market segments (such as desert and trekking tourism, thalassic-therapy) reported better prospects. They looked back on long years of often exclusive co-operation with small- and medium-sized niche operators in Germany, whose customer numbers have remained relatively constant. Given the diversification of tourism production pursued by the Moroccan government, especially in peripheral areas, incoming agencies in established co-operations, and who are able to respond flexibly to market conditions, considered they would have an advantage in deflecting some of the competitive pressures from larger operators.

\section{Reconciling intercultural positions}

German businesses mainly subscribed to a culture-free approach towards partners. They were concerned with the effective and optimal operation of commercial partnerships whereas cultural aspects were mainly seen as a burden not as a resource. Their relationships with Moroccan partners were on the whole positive, although their behaviour was characterised by relatively low levels of intercultural competence and a propensity to revert to stereotype. Cultural barriers to effective business such as time management, conflict-resolution and gender-specific experiences proved more irksome than business-related differences. Strict adherence to religious doctrine as well as the frequent use of family and relatives in the Moroccan labour force were disconcerting.

Their culture-free approach is further evident in their strategies and tactics for dealing with their Moroccan partners. Their initial strategies have strong resonances with Lukes' "second and third dimensions of power". German businesses attempted to keep culture off the commercial agenda and they attempted to establish what was in their Moroccan counterparts' real interests: namely, to adopt a much more systematic approach to business operations, reminiscent of German (i.e. western) methods in which business is for business' sake. Rather than an asset, the entwining of family and culture in operations presented a threat to the legitimate and expert power plays in their culture-free approach. Knowledge, remunerative power and, where necessary, coercive power were the bases of power while their structural position, expertise and opportunity were the sources of power. Tactics of rational persuasion, exchange and pressure were used as basic starting points in their commercial dealings with Moroccan partners.

The German business' preference for non-contractual arrangements might be seen as contradictory, but it reflects their relative empowerment. Where German businesses perceived themselves in control of a commercial relationship, they felt suitably empowered. Although they were prepared to tolerate what they saw as the negative aspects of working with Moroccan partners, ultimately they perceived control because they felt their commercial lessons were being received and they held the ultimate sanction: they could terminate the relationship at any time to lessen their exposure to risk. Nonpayment was also used as a punitive measure to reinforce control. German businesses felt that Moroccan entrepreneurs needed a com- 
mercial arrangement with them more than they needed one with the Moroccans. Although Moroccan partners were demanding better terms and conditions, they were chasing relationships with a declining number of German operators, businesses on which they relied to deliver large numbers of visitors, and businesses which understood their dependency.

Culture and business were on the whole bound for Moroccan enterprises. They did not isolate obvious differences in cultural traits with their German colleagues as principal sources of conflict, nor did they revert to stereotypes of German culture as explanations of business tensions. Major complaints surrounded unequal power relations, commercial demands and flows of information which favoured German businesses, which were perceived to value their own profitability at the expense of their Moroccan partners. Importantly, economic considerations were not separated from cultural ones. To Moroccan enterprises, the unfamiliar business practices and allegedly unfair position their partners had assumed were read as synonymous with globalising western culture, values and social practices; that is, the German business model was read by the Moroccans not as culture-free, not detached from culture, but as bound to Western culture.

Moroccan businesses used overt strategies more reminiscent of Lukes' "first dimension of power". They sought to get certain fundamental issues on the agenda with their German partners. These included consideration of basic terms such as payment and cash flow, as well as (quality) standards of service and the nature of routine operations. Knowledge and remunerative power were the bases of power while expertise and opportunity typically formed the sources of power. Upwards appeals, ingratiation and inspirational appeals were initially used. Moroccan enterprises had bases of expert power and informational power given their knowledge of local culture, markets and service opportunities, but their reward and hence coercive power through their ability to frustrate service relations was latent. The Moroccan respondents had less grandiose expectations for their relationships with German partners. As lifestyle enterprises, empowerment was manifest in their entering commercial arrangements with overseas partners and retaining them; to grow the relationship or to extract even modestly better terms and conditions was even more favourable given the marginal nature of many of the businesses and the substantial benefits the German businesses could deliver. Moroccan businesses felt disempowered because government policy made them more vulnerable through the development of new products and markets. Moroccan businesses, after all, had to carry the costs and risks of product development.

On this basis, one may have expected the German and Moroccan businesses to adopt different conflict resolution strategies. Both were loathe to seek redress in the law or costly commercial solutions. Instead, both reverted to the long-term social capital they had developed with their co-operators as the basis for reconciliation which at first glance subscribed to the culturally-bound approach. Personal relationships, discussions and meetings were primarily used to resolve differences and to reinforce the commercial relationships. Some elements of the individualistic culture approach to conflict management were present: namely, conflicts occur and have to be solved; they are rooted in fact; and they are open and direct. Similarly, several collective culture traits were evident such as the perception of conflicts as negative and destructive, closely associated with individuals and status, and intuitively played out.

\section{Conclusion}

The mediation of tourism experiences as products involves a number of actors and stakeholders in commercial relationships which sometimes span significant spatial and cultural distances. Perhaps unlike any other commodity, tourism is unique in just how far "many organisations recognise their interdependence and need to co-ordinate their activities through (...) relationships with other organisations, [but] they are also compelled by competitive forces and legal responsibilities to maintain their independence and autonomy." (WATKINS/BELL 2002, 15). This duality of interdependence - independence is at the heart of a series of distinctive power relations resulting from the inter-cultural communications between German and Moroccan enterprises. In the past, studies of tourism have attempted to ascribe power in general terms. The position of an actor within commodity chains or channels of distribution and/or access to information and other indicators were seen as surrogates of an 
actor's power. Actors use more subtle sets of tactics rooted in bases and sources of power, and their use of power in the everyday life is not always entirely as predicted by intricate bodies of theory. Not only do power relations vary over time, they are contingent on the nature of the relations between the actors at any given moment and the cultural backgrounds of the actors. Power is fluid, and simplified binaries such as powerful vs. powerless do not do justice to the subtleties of relations where the powerful can be challenged and the powerless can find sources of power in apparently unpromising circumstances.

There are two wider implications which relate to power as a core concept in the social sciences. The first is that constructs of power should be more firmly at the centre of the agenda of critical tourism research. As COLES/ Church (2006) have argued, "Far from being total strangers, tourism and power are often mentioned in the same breath. (...) Our challenge is to progress beyond often infrequent, partial and even plainly opportune treatments of power in tourism. Power is not a convenient conceptual 'port of call', a loosely-defined notion that handily serves to explain ambiguous asymmetries among different stakeholders in the development process, or which helps to describe vaguely the unequal allocation of resources." More routine and systematic naming and locating of power is vital if tourism analysis is to progress from a state characterised by selective linkages with established and emergent discourses of power (COLES/ CHURCH 2006). As a second implication, we would suggest that studies of tourism and in geography would benefit from casting the conceptual net much wider. Power is an inherently contested concept and there are several major bodies of power theory (HAUGAARD 2002). These are routinely discussed in power discourse, but these ideas have not always been widely discussed in the social sciences. Rather, treatments of power in disciplines such as geography have been dominated by Foucault's ideas which have become extremely fashionable if not to say relevant to research agendas in the past two decades. Indeed, their popularity, and that of post-structural approaches more widely (MURDOCH 2005), has served practically to discipline other perspectives on power off the scholarly radar. However, it should be noted, that, while there is considerable merit in $\mathrm{Fou}$ cault's thinking, it is not without its limitations, and hence it should not be either an automatic or exclusive choice as a framework for understanding power relations in contemporary society and economy. We approached power in bilateral business relations by using LUKES (1974) three dimensions of power as our starting point. Through a more plural, even pragmatic approach to revealing power of the type practised in organizational studies, these were complemented by perspectives on power tactics originating from social psychology. Similar to critiques of Foucault, there are limits to both these sets of thinking, but this more flexible approach is both appropriate and deepens our understanding of the complex, messy and sometimes simplified and instrumental perceptions of power within businesses and among the employees. Epistemologically, a Foucauldian reading of German-Moroccan bilateral relations could have been attempted and this may have produced different outcomes, but it would have been none the more or less scholastically valid.

\section{References}

Allen, J. (2003): The lost geographies of power. Oxford.

AtelJevic, I./DooRne, S. (2000): "Staying within the fence": Lifestyle entrepreneurship in tourism. In: Journal of Sustainable Tourism, (8)5, 378-392.

Bacharach, P./Baratz, M.S. (1962): Two faces of power. In: American Political Science Review, 56, 941 952.

Bacharach, P./ Baratz, M.S. (1970): Power and poverty: Theory and practice. New York.

BaCharach, S.B./ LAwLER, E.J. (1980): Power and politics in organizations: The social psychology of conflict, Coalitions and Bargaining. San Francisco.

Bastakis, C./ Buhalis, D./ Butler, R. (2004): The perception of small- and medium-sized tourism accommodation providers on the impacts of the tour operators' power in Eastern Mediterranean. In: Tourism Management, 25, 151-170.

Benfari, R.C./ Wilkinson, H.E./ ORTh, C.D. (1986): The effective use of power. In: Business Horizons, 29, May-June, 12-16.

Benton, T. (1981): "Objective" interests in the sociology of power. In: Sociology, 15, 161-184.

BIANCHI, R. (2002): Towards a new political economy of global tourism. In: Sharpley, R./ Telfer, D. (eds.): Tourism and development: Concepts and issues. Clevedon, 265-299.

Bourdieu, P. (1989): Satz und Gegensatz: Über die Verantwortung des Intellektuellen. Berlin. 
BRANNEN, M.Y. (2003): What is culture and why does it matter? Current conceptualizations of culture from anthropology. In: Boyacigiller, N.A./ Goodman, R.A./ Phillips, M.E. (eds.): Crossing cultures: Insights from master teachers. New York, 20-37.

BRITTON, S. (1991): Tourism, capital, and place: towards a critical geography of tourism. In: Environment and Planning D - Society and Space, 9, 451-478.

BRown, K./ Rosendo, S. (2000): Environmentalists, rubber tappers and empowerment: the politics and economics of extractive reserves. In: Development and Change, 31, 201-227.

BRUINS, J. (1999): Social power and influence tactics: a theoretical introduction. In: Journal of Social Issues, (55) 1, 7-14.

Buchanan, D./ BADHAM, R. (1999): Power, politics and organizational change: Winning the turf game. London.

BuchanAn, D./ HuCZYNSKI, A. (2004): Organizational behaviour: An introductory text. Harlow.

Bugental, D.B./ Lewis, J.B. (1999): The paradoxical misuse of power by those who see themselves as powerless: how does it happen? In: Journal of Social Issues, (55) $1,51-54$.

Cheong, S-M./ Miller, M.L. (2000): Power and tourism: A Foucauldian observation. In: Annals of Tourism Research, (27)2, 371-390.

Clancy, M. (1998): Commodity chains, services and development: theory and preliminary evidence from the tourism industry. In: Review of International Political Economy, (5)1, 122-148.

ClegG, S. (1989): Frameworks of power. London.

Coles, T.E./Church, A. (2006): Tourism and the forgotten entanglements of power. In: Church, A./ Coles, T.E. (eds.): Tourism, power and space. London.

Collier, M.J. (1989): Cultural and intercultural communication competence: current approaches and directions for future research. In: International Journal of Intercultural Relations, (13)3, 287-302.

De Dreu, C.K.W. (1997): Productive conflict: the importance of conflict management and conflict issue. In: De Dreu, C.K.W./ Van de Vliert, E. (eds.): Using conflict in organizations. London, 9-22.

Doorne, S. (1998): Power, participation and perception: an insider's perspective on the politics of the Wellington Waterfront redevelopment. In: Current Issues in Tourism, (1)2, 129-166.

FEw, R. (2002): Researching actor power: analyzing mechanisms of interaction in negotiations over space. In: Area, (34)1, 29-38.

French, J.R.P/RAVEN, B.H. (1959): The bases of social power. In: Cartwright, D. (ed.): Studies in social power. Ann Arbor, 150-167.

GiLbERT, D.-U. (1998): Konfliktmanagement in international tätigen Unternehmen: Ein diskursethischer Ansatz zur Regelung von Konflikten im interkulturellen Management. Sternenfels.

HANNAM, K. (2002): Tourism and development I: globalization and power. In: Progress in Development Studies, (2)3, 227-234.
HaugaARd, M. (2002): Power: A reader. Manchester.

HaugaARD, M. (2003): Reflections on seven ways of creating power. In: European Journal of Social Theory, (6) $1,87-113$.

Heiskala, R. (2001): Theorizing power: Weber, Persons, Foucault and neostructuralism. In: Social Science Information, (40)2, 241-264.

Herrod, A./ Wright, M. (2002): Geographies of power: Placing scale. Oxford.

HindESs, B. (1996): Discourses of power: From Hobbes to Foucault. Oxford.

HockER, J.L./ WiLMOT, W.W. (1995): Interpersonal conflict. Madison.

Hofstede, G. (1982): Culture's consequences: International differences in work-related values. Newbury Park.

Hofstede, G. (1999): The universal and the specific in 21st-century global management. In: Organizational Dynamics, (28)1, 34-43.

HOLLINSHEAD, K. (1999): Surveillance of the worlds of tourism: Foucault and the eye-of-power. In: Tourism Management, 20, 7-23

Hopfinger, H./SCHERLE, N. (2003): International co-operation and competition in tourist enterprises - cultural and economic aspects of their behaviour. In: Kopp, $\mathrm{H}$. (ed.): Area studies, business and culture: Results of the Bavarian research network forarea. Münster, 397-409.

HUCZYNSKI, A.A. (1996): Influencing within organizations: Getting in, rising up and moving on. Hemel Hempstead.

HunTER, W.C. (2001): Trust between culture: the tourist. In: Current Issues in Tourism, (4)1, 42-67.

IOANNIDES, D. (1998): Tour operators: the gatekeepers of tourism. In: Ioannides, D./ Debbage, K.G. (eds.): The economic geography of the tourist industry: a supplyside analysis. London, 139-158.

JACK, G./ PHIPPS, A. (2005): Tourism and interrcultural exchange: Why tourism matters. Clevedon.

JOHNSON, D./ TuRner, C. (2003): International business: Themes and issues in the modern global economy. London.

KAYAT, K. (2002): Power, social exchanges and tourism in Langkawi: rethinking resident perceptions. In: International Journal of Tourism Research, 4, 171-191.

KIPNIS, D./SCHMIDT, S.M./WILKINSON, I. (1980): Intraorganizational influence tactics: explorations in getting one's own way. In: Journal of Applied Psychology, 65, 440-452.

Knights, D./McCABE, D. (2002): A road less travelled: Beyond managerialist, critical and processual approaches to total quality management. In: Journal of Organizational Change, (15)3, 235-254.

Knights, D./Willmott, H. (1999): Management lives: Power and identity in work organizations. London.

KOPPER, E. (1992): Multicultural workgroups and project teams. In: Bergemann, N./Sourisseaux, A.L.J. (Hrsg.): Interkulturelles Management. Heidelberg, 229252. 
KÜHLmanN, T.M./ Stahl, G.K. (1998): Diagnose interkultureller Kompetenz: Entwicklung und Evaluierung eines Assessment Centers. In: Barmeyer, C.I./ Bolten, J. (Hrsg.): Interkulturelle Personalorganisation. Sternenfels, 213-224.

KuRAN, T. (2004): Islam and mammon: the economic predicaments of Islamism. Princeton.

KutschKer, M./Schmid, S. (2002): Internationales Management. München.

LATOUR, B. (1986): The powers of association. In: Law, J. (ed.): Power, Action and Belief: A new sociology of knowledge. London, 264-280.

LAW, J. (2004): After method: Mess in social science research. London.

LIU, Z. (2003): Sustainable tourism development: a critique. In: Journal of Sustainable Tourism, (11)6, 459-475.

Lukes, S. (1974, 2005): Power: A radical view. Basingstoke.

ManN, M. (1986): The sources of social power. Vol. 1: A history of power from the beginning to AD 1760 . New York.

ManN, M. (1993): The sources of social power. Vol. 2: The rise of classes and nation-states, 1760-1914. New York.

McKinley, A./ Starkey, K. (eds.)(1998): Foucault, management and organization theory. London.

Moosmüller, A. (1997): Kulturen in Interaktion: Deutsche und US-amerikanische Firmenentsandte in Japan. Münster.

Moran, R.T./ HARRIS, P.R./ STRIPP, W.G. (1993): Developing the global organization: Strategies for human resource professionals. Houston.

Morriss, P. (2002): Power: A philosophical Analysis. Manchester.

Mosedale, J.T. (2005): Capital mobility in the tourism sector: An analysis of integrated corporations. Eastbourne. (Unpublished Paper presented at 'The End of Tourism? Mobility and Local-Global Connections', 2324 June 2005, Centre for Tourism Policy Studies, University of Brighton, Eastbourne, UK.).

Mowforth, M./MunT, I. (1998): Tourism and sustainability. Development and new tourism in the Third World. London.

NiENHAUS, V. (1996): Wirtschaftsordnungen im Islam. In: Geographische Rundschau, (48)6, 366-371.

OSTERLOH, M. (1994): Kulturalismus versus Universalismus: Reflektionen zu einem Grundlagenproblem des interkulturellen Managements. In: Schiemenz, B./ Wurl, H.-J.: (Hrsg.): Internationales Management: Beiträge zur Zusammenarbeit. Wiesbaden, 95-116.

PARSONS, T. (1963): On the concept of political power. In: Proceedings of the American Philosophical Society, (107)3, 232-262.

PoGgi, G. (2001): Forms of power. Oxford.

Popp, H. (Hrsg.) (1999): Lokale Akteure im Tourismus der Maghrebländer. Resultate der Forschungen im Bayerischen Forschungsverbund FORAREA 1996-1998. Passau.
PRUS, R. (1999): Beyond the power mystique: Power as intersubjective accomplishment. Albany.

RAVEN, B.H. (1965): Social influences and power. In: Steiner, I.D./Fishbein, M. (eds.): Current studies in social psychology. New York, 371-382.

RAVEN, B.H. (1974): The comparative analysis of power and power preference. In: Tedeschi, J.T. (ed.): Perspectives on social power. Chicago, 172-198.

RAVEN, B.H. (1992): A power/interaction model of interpersonal influence: French and Raven thirty years later. In: Journal of Social Behaviour and Personality, 7, 217-244.

REED, M.G. (1997): Power relations and communitybased tourism planning. In: Annals of Tourism Research, (24)3, 566-591.

ReIsinger, Y./TuRneR, L.W. (2003): Cross-cultural behaviour in tourism: Concepts and analysis. Oxford.

Rugman, A.M./HodgetTs, R.M. (2003): International business. Harlow.

SCHERLE, N. (2004): International bilateral business in the tourism industry: perspectives from German-Moroccan co-operations. In: Tourism Geographies, (6)2, 229-256.

SCHERLE, N. (2006): Bilaterale Unternehmenskooperationen im Tourismussektor: Ausgewählte Erfolgsfaktoren. Wiesbaden.

SCHNEIDER, S.C./ BARSOUX, J.-L. (1999): Managing across cultures. London.

SoFIELD, T.H.B. (2003): Empowerment for sustainable tourism development. Oxford.

StewART, A. (2001): Theories of power and domination. London.

Thomas, A.B. (2003): Controversies in management: Issues, debates, answers. London.

Thomas, R./THOMAs, H. (2005): Understanding tourism policy-making in urban areas, with particular reference to small firms. In: Tourism Geographies, (7)2, 121-137.

Tiger, L. (2000): Power is a liquid, not a solid. In: Social Science Information, (39)1, 5-16.

TRIBE, J. (2003): The RAE-ification of tourism research in the UK. In: International Journal of Tourism Research, 5, 225-234.

URRY, J. (2002): The tourist gaze. London.

Vorlaufer, K. (1998): Die Globalisierung der Tourismuswirtschaft. In: Gebhardt, H./Heinritz, G./Wiessner, R. (Hrsg.): Europa im Globalisierungsprozess von Wirtschaft und Gesellschaft. Stuttgart, 66-76.

Watkins, M./BELl, B. (2002): The experience of forming business relationships in tourism. In: International Journal of Tourism Research, (4)1, 15-28.

WeAver, D. (2004): Tourism and the elusive paradigm of sustainable development. In: Lew, A.A./Hall, C.M./Williams, A.M. (eds.): A companion to tourism. Oxford, 510-521.

YuKL, G./FALBE, C.M. (1990): Influence tactics and objectives in upward, downward and lateral influence attempts. In: Journal of Applied Psychology, (75)2, 132140. 